\title{
Inhibition of phosphatidylinositol-3 kinase/Akt or mitogen-activated protein kinase signaling sensitizes endothelial cells to TNF- $\alpha$ cytotoxicity
}

\author{
L Zhang ${ }^{1}$, T Himi ${ }^{1}$, I Morita ${ }^{\star, 1}$ and S Murota ${ }^{1}$ \\ ${ }^{1}$ Department of Cellular Physiological Chemistry, Graduate School, Tokyo \\ Medical and Dental University 1-5-45 Yushima, Bunkyo-ku, Tokyo 113-8549, \\ Japan \\ * Corresponding author: I Morita, PhD, Department of Cellular Physiological \\ Chemistry, Graduate School, Tokyo Medical and Dental University, 1-5-45 \\ Yushima, Bunkyo-ku, Tokyo 113-8549, Japan Tel: +81-3-5803-5575; \\ Fax: +81-3-5803-0212; E-mail: morita.cell@tmd.ac.jp
}

Received 17.8.00; revised 27.11.00; accepted 14.12.00

Edited by DR Green

\begin{abstract}
Bovine carotid artery endothelial (BAE) cells are resistant to tumor necrosis factor- $\alpha$ (TNF), like most other cells. We examined if mitogen-activated protein (MAP) kinase and phosphatidylinositol-3 (PI3) kinase/Akt pathways are involved in this effect. In BAE cells, TNF activates MAP kinase in a MAP kinase kinase 1 (MEK1) manner and Akt in PI3-kinasedependent manner. Pretreatment with either the MEK1 inhibitor U0126 or PI3-kinase inhibitor LY294002 sensitized BAE cells to TNF-induced apoptosis. Neither U0126 nor LY294002 pretreatment affected TNF-induced activation of $\mathrm{NF}-k \mathrm{~B}$, suggesting that the MAP kinase or PI3-kinase/Aktmediated anti-apoptotic effect induced by TNF was not relevant to NF- $k$ B activation. Both MAP kinase and PI3kinase/Akt -mediated signaling could prevent cytochrome $c$ release and mitochondrial transmembrane potential $(\Delta \psi)$ decrease. PI3-kinase/Akt signaling attenuated caspase-8 activity, whereas MAP kinase signaling impaired caspase-9 activity. These results suggest that TNF-induced MAP kinase and PI3-kinase/Akt signaling play important roles in protecting BAE cells from TNF cytotoxicity. Cell Death and Differentiation (2001) 8, 528-536.
\end{abstract}

Keywords: apoptosis; tumor necrosis factor- $\alpha$; MAP kinase; PI3kinase; Akt

Abbreviations: BAE cells, bovine carotid artery endothelial cells; TNF, tumor necrosis factor- $\alpha$; MAP kinase, mitogen-activated protein kinase; PI3-kinase, phosphatidylinositol-3 kinase; $\Delta \psi$, mitochondrial transmembrane potential; NF- $\kappa \mathrm{B}$, nuclear factor $\kappa \mathrm{B}$

\section{Introduction}

Tumor necrosis factor- $\alpha$ (TNF) is a pleiotropic cytokine that exerts a wide range of cellular effects including apoptosis, proliferation, differentiation and inflammation. TNF executes its biological activities through two distinct cell membrane receptors, TNFR1 (P55) and TNFR2 (P75). ${ }^{1}$ TNF elicits its cell-killing effect through binding to TNFR1. This binding induces TNFR1 trimerization, recruits procaspases such as procaspase-8 via several adaptor proteins, the so-called TNFR1-associated death domain protein (TRADD) and Fasassociated death domain protein (FADD). ${ }^{2,3}$ The recruitment of procaspases drives its activation through self-cleavage, then the activated caspases trigger other downstream caspases directly or indirectly via the mitochondrial apoptotic pathway and ultimately leading to apoptosis. ${ }^{1,4,5}$ In addition to transducing apoptotic signaling, TRADD also interacts with other two proteins, TNFR-associated factor 2 (TRAF2) and receptor-interacting protein (RIP) to participate in c-Jun $\mathrm{N}$ terminal kinase (JNK) and nuclear factor $-\kappa \mathrm{B}(\mathrm{NF}-\kappa \mathrm{B})$ activations. ${ }^{6-8}$ Although TNF induces death in many tumor cells or infected cells, most normal cells are resistant. However, these resistant cells can be sensitized to TNFinduced apoptosis by pretreatment with protein or RNA synthesis inhibitors such as cycloheximide or actinomycin D. ${ }^{9-11}$ Conversely, pretreatment of TNF-sensitive cells with TNF increases their resistance to subsequent TNF challenges. ${ }^{12}$ These findings suggest that TNF not only induces cell death but also elicits protective signals to counteract cytotoxicity, and the fate of cells to die or to live is due to the balance between this two opposing kinds of activities. To date, the main body of knowledge in understanding the TNFinduced self-control mechanism focuses on NF- $\kappa \mathrm{B}$, a transcription factor activated by TNF and regulates production of many anti-apoptotic proteins to counteract the TNFinduced cytotoxic effect. ${ }^{13,14}$ A series of experiments revealed that $\mathrm{NF}-\kappa \mathrm{B}$ is responsible for the TNF-induced protective effect. $^{7,15-18}$ However, recent studies showed that the cells derived from TRAF2-deficient mice are more susceptible to TNF cytotoxicity even though NF- $\kappa \mathrm{B}$ is activated by TNF. ${ }^{19}$ Given the complexity of TNF signaling pathways, it is apparent that other protective signaling may exist in addition to that of NF- $\kappa \mathrm{B}$. However, the identities and mechanisms of these protective signaling have yet to be clarified.

Recently, PI3-kinase/Akt pathway and MAP kinase pathways have been implicated in transducing survival signaling in a wide range of cell types. ${ }^{20-24}$ PI3-kinase phosphorylates the third-position of the inositol ring to produce a family of three phosphoinositides that are important cellular second messengers. One of the targets of PI3-kinase is the serine/threonine protein kinase Akt, 
which is proposed to inhibit apoptosis by inactivating several key substrates in apoptotic cascade such as procaspase- $9,{ }^{25}$ proapoptotic protein $\mathrm{BAD},{ }^{26}$ and transcription factor FKHRL1. ${ }^{21,27}$ The MAP kinase signaling pathway is reported to exert antiapoptotic effect by transcriptiondependent (regulation of $\mathrm{Bcl}-2$ induction) and -independent mechanism (phosphorylation of BAD). ${ }^{23}$ In the present study, we focused on these two survival signaling pathways to investigate whether and how these two pathways regulate the TNF-induced self-control machinery. We found that inhibition of PI3-kinase/Akt or MAP kinasemediated signaling potentiated TNF-induced apoptosis in bovine carotid artery endothelial (BAE) cells, and these two pathways protected BAE cells from apoptosis by distinct mechanisms.

\section{Results}

\section{TNF activates MAP kinase and Akt kinase in BAE cells}

We first investigated whether TNF can activate MAP kinase and Akt, which is downstream target of PI3-kinase. Since activation of MAP kinase and Akt is dependent on phosphorylation of molecules at definite sites, we can determine the activations of these two kinases by using specific phosphorylated antibodies. Treatment of BAE cells with $10 \mathrm{ng} / \mathrm{ml}$ TNF induced MAP kinase phosphorylation within $5 \mathrm{~min}$, and this activation lasted up to $1 \mathrm{~h}$ after stimulation. The increase in MAP kinase activity peaked between 20-30 min, and $10 \mu \mathrm{M}$ U0126, a specific inhibitor of MAP kinase kinase (MEK1), reduced TNF-induced MAP kinase activity to basal levels (Figure 1A). TNF (10 ng/ml) also induced Akt phosphorylation while a specific PI3-kinase inhibitor, LY294002, completely
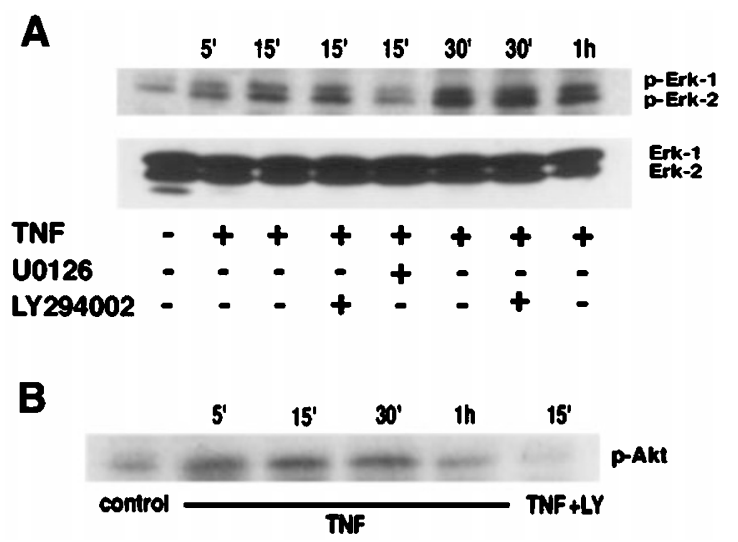

Figure 1 TNF activates Akt and MAP kinase in BAE cells. (A) BAE cells were incubated with or without U0126 $(10 \mu \mathrm{M})$ or LY294002 $(10 \mu \mathrm{M})$ for $30 \mathrm{~min}$, then stimulated with or without TNF $(10 \mathrm{ng} / \mathrm{ml})$ for the different durations as indicated. Cell extracts were immunoblotted with anti-active MAP kinase antibody ( $p$-Erk) (upper panel) or anti-extracellular regulated kinase (Erk) antibody (lower panel). Similar results were obtained from three independent experiments. (B) BAE cells were treated with or without (control) TNF (10 ng/ $\mathrm{ml})$ in the presence (TNF+LY) or absence of LY294002 $(10 \mu \mathrm{M})$ for the indicated times. Cell extracts were immunoblotted with anti-phosphoAkt ( $p$ Akt). Similar results were obtained from three independent experiments suppressed Akt phosphorylation at the dose of $10 \mu \mathrm{M}$ (Figure $1 \mathrm{~B})$, suggesting that TNF-induced Akt activation is through a PI3-kinase-dependent pathway. As shown in Figure 1A, LY294002 did not affect TNF-induced MAP kinase activation, suggesting that TNF-induced MAP kinase and Akt activation derived from distinct pathways.

\section{Inhibition of MAP kinase or PI3-kinase/Akt signaling potentiates TNF-induced apoptosis in BAE cells}

To investigate whether MAP kinase or PI3-kinase/Aktmediated signaling could be involved in the TNF self-control machinery, we examined whether inhibition of these two kinase pathways would affect susceptibility of BAE cells to TNF by using LY294002 and U0126. To investigate the effect of signaling induced by TNF clearly, we removed serum from the culture medium of BAE cells for $14 \mathrm{~h}$ before treatment and during all treatment periods, and this serum starvation resulted in $10 \%$ basal apoptosis. Treatment of the cells with $10 \mathrm{ng} / \mathrm{ml}$ TNF for $20 \mathrm{~h}$ resulted in $20-25 \%$ of cells undergoing apoptosis (Figure 2B) while most of the cells in this experimental condition displayed normal morphology with regularly dispersed chromatin (Figure $2 \mathrm{~A}$ ). Preincubation with LY294002 $(10 \mu \mathrm{M})$ or U0126 $(10 \mu \mathrm{M})$ for $30 \mathrm{~min}$ before TNF (10 ng/ml) treatment, however, significantly increased apoptotic cells up to $80-90 \%$ and $55-65 \%$, respectively (Figure 2B). The dead cells detached and displayed typical apoptotic morphology, such as condensation of chromatin and fragmentation of nucleus (Figure 2A). LY294002 or U0126 treatment alone did not show any apoptosis-induced effect (Figure 2B,C), suggesting that the dosage of inhibitors we used here is not toxic to cells. Similar results were also obtained from an MTT assay (Figure 2C).

\section{LY294002 and U0126 do not affect NF- $\kappa$ B activation induced by TNF}

It has been reported that $\mathrm{NF}-\kappa \mathrm{B}$ is responsible for the resistance of cells to the cytotoxicity of TNF. ${ }^{16-18}$ Recently, Akt has been shown to be both necessary and sufficient for the activation of NF- $\kappa \mathrm{B}$ induced by TNF or platelet-derived growth factor (PDGF). ${ }^{28,29}$ The $90 \mathrm{kDa}$ ribsomal S6 kinase $\left(\mathrm{pp} 90^{\text {rsk }}\right)$, the downstream target of MAP kinase, could also activate NF- $\kappa \mathrm{B} .{ }^{30,31}$ Accordingly, it is possible that inhibition of MAP kinase or Akt-mediated signaling potentiates the cytotoxicity of TNF by preventing the activation of NF- $\kappa \mathrm{B}$. Therefore, we examined whether LY294002 or U0126 could interfere with NF- $\kappa \mathrm{B}$ activation. NF- $\kappa \mathrm{B}$ exists in cytoplasm in a complex form with the inhibitory protein $\mathrm{I}_{\kappa} \mathrm{B}$ in resting cells. Upon stimulation, $I \kappa B$ is phosphorylated rapidly and subsequently degraded by proteasomes. NF- $\kappa \mathrm{B}$ is released from $I_{\kappa} \mathrm{B}$, translocated to the nucleus and activates various genes carrying the NF- $\kappa \mathrm{B}$ response element. ${ }^{32}$ To monitor NF- $\kappa \mathrm{B}$ activation, we examined $\mathrm{I}_{\kappa} \mathrm{B}$ degradation and $\mathrm{NF}-\kappa \mathrm{B}$ nuclear translocation. TNF induced $\mathrm{I}_{\kappa} \mathrm{B}$ degradation (Figure $3 \mathrm{~A}$ ) and $\mathrm{NF}-\kappa \mathrm{B}$ nuclear translocation (Figure $3 \mathrm{~B}$ ), and pretreatment of LY294002 $(10 \mu \mathrm{M})$ or U0126 $(10 \mu \mathrm{M})$ before TNF stimulation did not exert any influence on either $I_{\kappa} \mathrm{B}$ degradation (Figure $3 \mathrm{~A}$ ) or NF- $\kappa \mathrm{B}$ nuclear translocation (Figure $3 \mathrm{~B}$ ). These results 

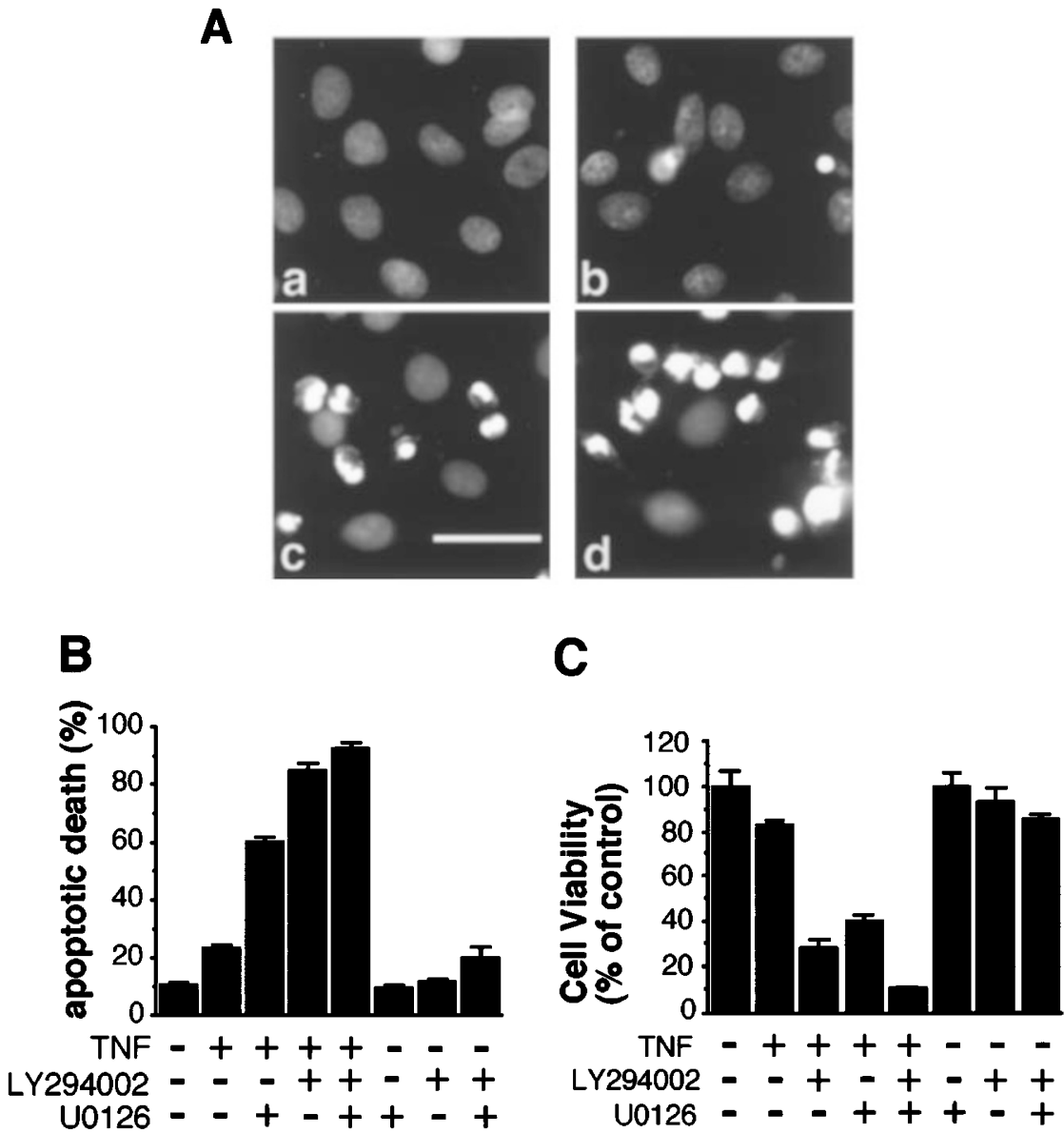

Figure 2 Effect of LY294002 or U0126 on TNF-induced apoptosis. (A) Morphological appearance of BAE cells incubated for $20 \mathrm{~h}$ with MEM alone (a), $10 \mathrm{ng} / \mathrm{ml}$ TNF (b), $10 \mathrm{ng} / \mathrm{ml} \mathrm{TNF}+10 \mu \mathrm{M}$ U0126 (c), or $10 \mathrm{ng} / \mathrm{ml} \mathrm{TNF}+10 \mu \mathrm{M}$ LY294002 (d). Nuclear alteration were visualized by Hoechst 33342 staining. Scale bar $=50 \mu \mathrm{m}$. (B) BAE cells were treated with or without various reagents as indicated for $20 \mathrm{~h}$, then the cells were stained with Hoechst 33342 and apoptotic cells were assessed as described in Materials and Methods. The experiments were performed in triplicate. (C) BAE cells were treated with or without various reagents as indicated for $20 \mathrm{~h}$, then the cell survival were detected by MTT assay as described in Materials and Methods. Similar results were obtained from three independent experiments. Values represent means \pm S.E.M. $(n=6)$

suggested that MAP kinase or PI3-kinase/Akt-mediated antiapoptotic effects are through a NF- $\kappa \mathrm{B}$-independent pathway.

\section{Inhibition of MAP kinase or PI3-kinase/Akt signaling potentiates cytochrome $c$ release from mitochondria and induces mitochondrial transmembrane potential $(\Delta \psi)$ decrease}

Mitochondria dysfunction has been implicated in the execution of apoptosis. ${ }^{33,34}$ To investigate whether MAP kinase or PI3-kinase/Akt signaling inhibits TNF-induced apoptosis by maintaining the integrity of mitochondria, we examined whether inhibition of MAP kinase and PI3-kinase/ Akt signals would affect cytochrome $c$ release from mitochondria and alter mitochondrial transmembrane potential $(\Delta \psi)$. Immunofluorescent staining of BAE cells with an anti-cytochrome $c$ antibody exhibited a punctate staining pattern characteristic of mitochondrial localization (Figure 4A, a). Western blot analysis also revealed that cytochrome $c$ was localized in mitochondria (Figure 4B). Treatment of cells with TNF for $4 \mathrm{~h}$ did not alter the staining pattern of cytochrome $c$ in most of the cells (Figure 4A,b) and no release of cytochrome $c$ from mitochondria was evident (Figure 4B). TNF treatment also did not affect rhodamine 123 uptake as measured by flow cytometry (Figure 5). In the presence of LY294002 or U0126, however, the cells treated with TNF for $4 \mathrm{~h}$ showed a diffused staining pattern of cytochrome $c$ (Figure 4A,c,d), with significant increase of cytochrome $c$ in the cytosol fraction (Figure 4B), suggesting that cytochrome $c$ was released from mitochondria. No significant levels of cytochrome oxidase (subunit IV) was found in the cytosol fraction (Figure 4B), confirming that our subcellular fraction preparations were nearly free of mitochondrial contamination. Pretreatment of U0126 or LY294002 also increased the cells population with low $\Delta \psi$ (Figure 5), and pretreatment of cells with carbonyl cyanide m-chlorophenylhydrazone (CCCP), a protonophore that dissipates the mitochondrial inner membrane proton gradient, significantly decreased uptake of rhodamine 123 (Figure 5), suggesting that it is the uptake of rhodamine 123 that reflects $\Delta \psi$. These results suggest that PI3-kinase/Akt and MAP kinase-mediated protection may lie upstream of mitochondria. 
A

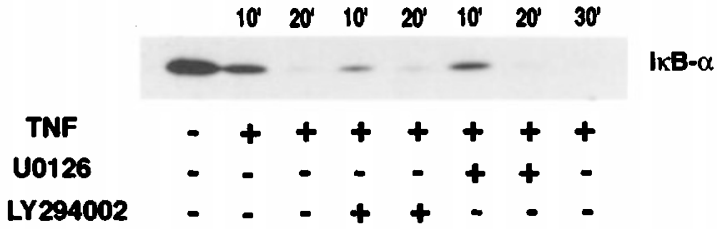

B
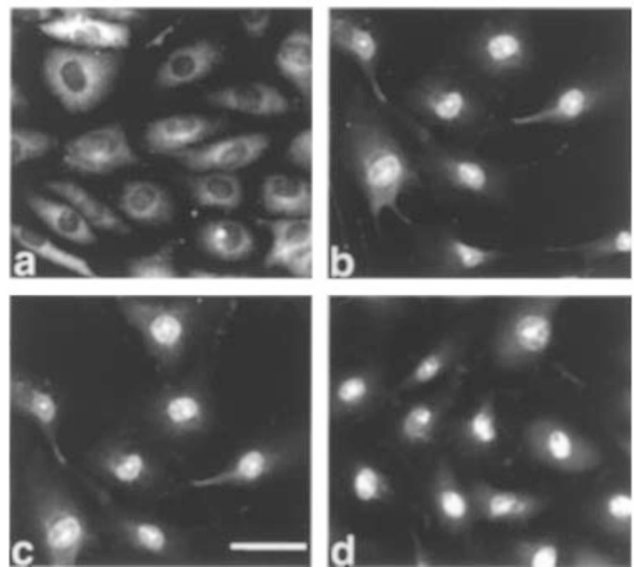

Figure 3 LY294002 and U0126 did not affect activation of NF- $k B$ induced by TNF. (A) BAE cells were incubated with or without U0126 $(10 \mu \mathrm{M})$ or LY294002 $(10 \mu \mathrm{M})$ for $30 \mathrm{~min}$, then stimulated with or without $10 \mathrm{ng} / \mathrm{ml}$ TNF for indicated times. Cells were lysed and immunoblotted with anti- $\left.\right|_{\kappa} \mathrm{B}-\alpha$ antibody. Similar results were obtained from three independent experiments. (B) BAE cells were incubated without (b) or with U0126 $(10 \mu \mathrm{M})(\mathrm{c})$ or LY294002 $(10 \mu \mathrm{M})$ (d) for $30 \mathrm{~min}$, followed by stimulation of $10 \mathrm{ng} / \mathrm{ml}$ TNF for $30 \mathrm{~min}$. For control, the cells were maintained in MEM without any additives (a). The cells were fixed and stained with anti-NF- $\kappa$ B antibody. Scale bar $=50 \mu \mathrm{m}$. Similar results were obtained from three independent experiments

\section{PI3-kinase/Akt and MAP kinase signaling protect BAE cells from apoptosis by distinct caspase pathways}

Caspase-8 is an initiator in the TNF-induced apoptotic signaling machinery. To investigate whether PI3-kinase/Akt and MAP kinase-mediated inhibition occur at the initial phases of TNF-induced apoptotic signaling, we examined the activation of caspase- 8 by measuring the cleavage of a specific fluorigenic substrate lle-Glu-Thr-Asp-7-amino-4-trifluoromethyl coumarin (IETD-AFC). As shown in Figure 6A, although treatment of cells with TNF $(10 \mathrm{ng} / \mathrm{ml})$ increased caspase-8-like protease activity, pretreatment with LY294002 significantly enhanced TNF-induced caspase-8-like protease activity. Pretreatment with U0126, however, did not affect TNF-induced caspase-8-like protease activity, and the combination of LY294002, U0126 and TNF contributed to the same enhancement of caspase-8-like protease activity as in the presence of LY294002 and TNF. We further confirmed this result by immunoblotting analysis. Treatment of cells with TNF $(10 \mathrm{ng} / \mathrm{ml})$ did not induce detectable caspase-8
A
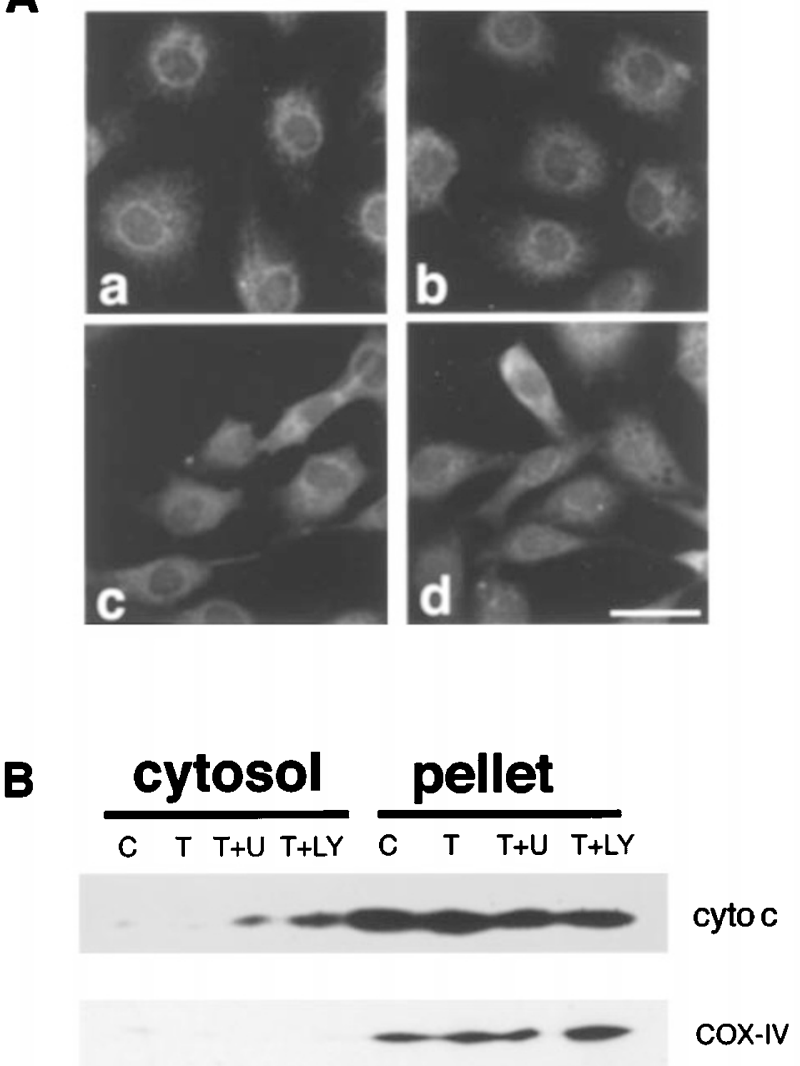

Figure 4 LY294002 and U0126 induced cytochrome $c$ release from mitochondria. (A) BAE cells were incubated for $4 \mathrm{~h}$ with MEM alone (a) or $10 \mathrm{ng} / \mathrm{ml} \mathrm{TNF}$ (b), or $10 \mathrm{ng} / \mathrm{ml} \mathrm{TNF}+10 \mu \mathrm{M}$ U0126 (c) and $10 \mathrm{ng} / \mathrm{ml} \mathrm{TNF}+10 \mu \mathrm{M}$ LY294002. The cells were fixed and stained with anti-cytochrome $c$ antibody. Scale bar $=50 \mu \mathrm{m}$. The experiments were performed in triplicate. (B) BAE cells were treated with or without (c) $10 \mathrm{ng} / \mathrm{ml}$ TNF in the absence (T) or presence U0126 $(10 \mu \mathrm{M})(\mathrm{T}+\mathrm{U})$ or $\mathrm{LY} 294002(10 \mu \mathrm{M})(\mathrm{T}+\mathrm{LY})$ for $4 \mathrm{~h}$. The cells were fractionated into cytosolic (cytosol) and organellar (pellet) fractions as described and then respective extracts were immunoblotted with anticytochrome $\mathrm{c}$ antibody (cyto $\mathrm{c}$; upper panel) or anti-cytochrome oxidase subunit IV antibody (COX-IV; lower panel). Similar results were obtained from three independent experiments

cleavage, and pretreatment of U0126 slightly induced caspase-8 cleavage. In the presence of LY294002, however, a clear procaspase-8 intermediate cleavage product was detected, this result was coincident with enzyme assay (Figure 6C). These observations suggest that PI3-kinase/Aktmediated protection occurs upstream of caspase-8, and MAP kinase-mediated inhibition of TNF-induced apoptosis may lie downstream of caspase-8.

In our present study, inhibition of PI3-kinase/Akt and MAP kinase signaling potentiated cytochrome $c$ release from mitochondria. Therefore we next assessed whether inhibition of PI3-kinase/Akt and MAP kinase signaling would affect the activity of caspase- 9 by measuring the cleavage of the specific fluoregenic substrate LEHD-AFC (Leu-Glu-His-Asp-7-amino-4-trifluoromethyl coumarin) and detecting caspase- 9 cleavage by immunoblotting analysis. TNF alone increased caspase-9-like activity. Pretreatment of cells with U0126, further evoked this enzyme activity 
a

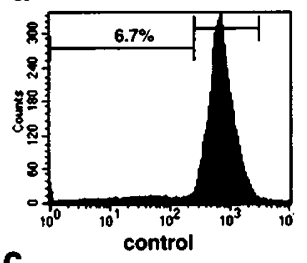

C

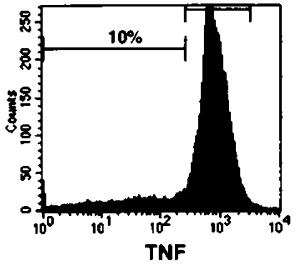

e

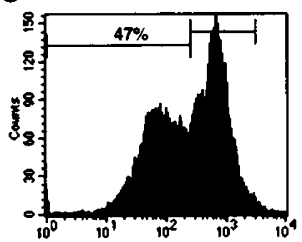

CCCP

Rhodamine 123

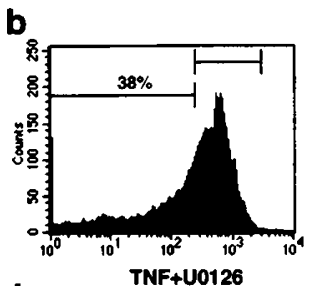

d

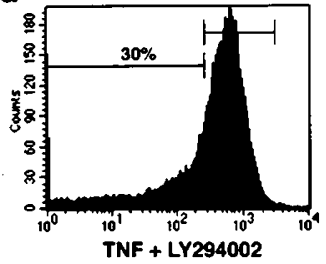

Figure 5 Pretreatment of cells with U0126 or LY294002 induced $\Delta \psi$ decrease. BAE cells were treated without (a) or with $10 \mathrm{ng} / \mathrm{ml}$ TNF in the absence (b) or presence U0126 (c) or LY294002 (d) as indicated for $4 \mathrm{~h}$, or with CCCP (e) for $30 \mathrm{~min}$, then loaded with rhodamine 123 for $15 \mathrm{~min}$. The levels of $\Delta \psi$ were determined by flow cytometric analysis. The experiments were performed in triplicate

increasing as expected. Pretreatment of the cells with LY294002, however, did not enhance TNF-induced caspase-9-like activity (Figure 6B). The same result was also observed in immunoblotting analysis by using an antibody that recognizes both procaspase- 9 and the cleavage product. As shown in Figure 6C, although TNF alone induced caspase-9 cleavage, in the presence of U0126, the amount of cleaved caspase-9 was significantly increased, and the amount of procaspase- 9 was decreased. In the presence of LY294002, however, no evident caspase- 9 cleavage was detected, and the protein level of procaspase- 9 was not decreased. These results suggest that MAP kinase-mediated protection occurs upstream of caspase- 9 .

\section{Discussion}

It has been known for many years that most normal cells are resistant to TNF cytotoxicity, and these resistant cells can be rendered sensitive to TNF-induced apoptosis by reagents that block the synthesis of mRNA or protein. ${ }^{9-11}$ These facts indicate that a self-control machinery exists in TNF-induced signaling pathways. TNF transduces one death signal eliciting cell death and triggers another survival signal that protects cells against apoptosis. Although $\mathrm{NF}-\kappa \mathrm{B}$ has been well documented as contributing to this machinery, recent studies reveal that in addition to $\mathrm{NF}-\kappa \mathrm{B},{ }^{13-18}$ other signals such as mitogen-activated protein kinase phosphatase-1 (MKP-1) ${ }^{35}$ and sphingosine kinase $(\mathrm{SphK})^{36}$ induced by TNF also contribute to the anti-apoptotic effect.

Accumulating evidence indicates that PI3-kinase/Akt and MAP kinase pathways convey survival signals to protect cells from apoptosis induced by various stimuli such as Fas ligation, growth factor withdrawal, serum deprivation, and UV irradiation. ${ }^{20-24,37-39}$ For instance, PI3-kinase/Akt is sufficient in preventing apoptosis induced by UV irradiation in Rat-1 fibroblast, ${ }^{38}$ and MAP kinase can protect Jurkat T cells from Fas-induced apoptosis. ${ }^{37}$ Our present study revealed that these two pathways also participate in the TNF self-control machinery by transducing survival signals. Although Akt and MAP kinase have been implicated in activation of NF- $\kappa \mathrm{B},{ }^{28-31}$ inhibition of MAP kinase and Akt did not have any effect on TNF-induced activation of NF$\kappa \mathrm{B}$, consistent with previous observations. ${ }^{40,41}$ This suggests that the anti-apoptotic effects mediated by MAP kinase and PI3-kinase/Akt are independent of NF- $\kappa \mathrm{B}$ activation in this system.

In our present study, TNF rapidly activated MAP kinase and Akt, and preincubation with the MEK1 inhibitor U0126 or the PI3-kinase inhibitor LY294002, impaired MAP kinase and Akt activation respectively, suggesting that TNF induces MAP kinase and Akt activation through MEK1dependent and PI3-kinase-dependent pathways. It has been demonstrated that TNF activates sphingomeylinase to produce ceramide, an important second messenger, which in turn activates MAP kinase through Raf/MEK kinase pathways. ${ }^{42}$ Ceramide also has been implicated in the activation of PI3-kinase induced by TNF, and additionally, TNF has been shown to activate PI3-kinase through the TNFR1/insulin receptor substrate 1 (IRS-1)/p85 signaling system. ${ }^{43,44}$ TNF may activate MAP kinase and Akt through these mechanisms in our present system as well.

Mitochondria have been shown to play a pivotal role in both apoptotic and nonapoptotic cell death. ${ }^{33,34}$ Mitochondria participate in the apoptotic process by releasing apoptogenic factors such as cytochrome $c$, apoptosisinducing factor (AIF) and procaspases from the intermembrane space to the cytoplasm. ${ }^{33,34}$ Once released into the cytoplasm, cytochrome $c$ binds with apoptosis proteaseactivating factor 1 (Apaf-1) and procaspase-9, which trigger a downstream caspase cascade in the present of ATP or dATP. ${ }^{4}$ In the present study, we observed that TNF did not induce any detectable cytochrome $c$ release from mitochondria or $\Delta \psi$ loss. However, inhibition of MAP kinase or PI3-kinase/Akt signaling significantly potentiated cytochrome $c$ release and induced significant $\Delta \psi$ decrease, suggesting that PI3-kinase/Akt and MAP kinase-mediated inhibition of TNF-induced apoptosis occurred upstream of mitochondria. Both MAP kinase and Akt could phosphorylate $B A D$ and prevent its association with $\mathrm{Bcl}-\mathrm{X}_{\mathrm{L}}$ or $\mathrm{Bcl}-2$, which in turn prevents cytochrome $c$ release. ${ }^{23,26}$ Akt could also inhibit cytochrome $c$ release by a BAD phosphorylation-independent mechanism. ${ }^{38}$ We did not address whether Akt or MAP kinase prevented mitochondria dysfunction and cytochrome $c$ release via phosphorylating $\mathrm{BAD}$; this mechanism needs to be further explored. Caspase-8 is an important initiator in the TNF-induced 
A

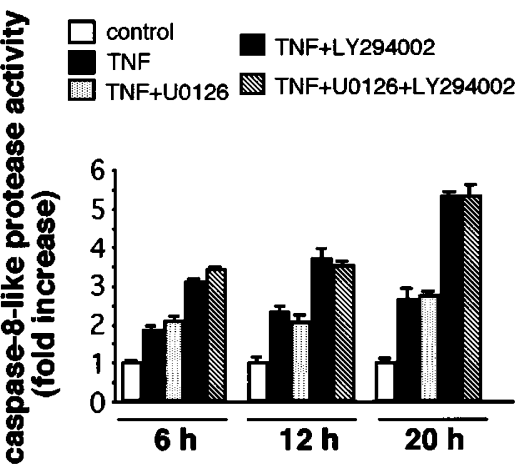

B

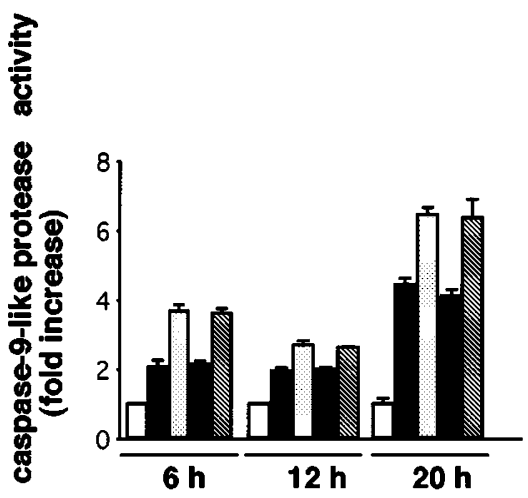

C

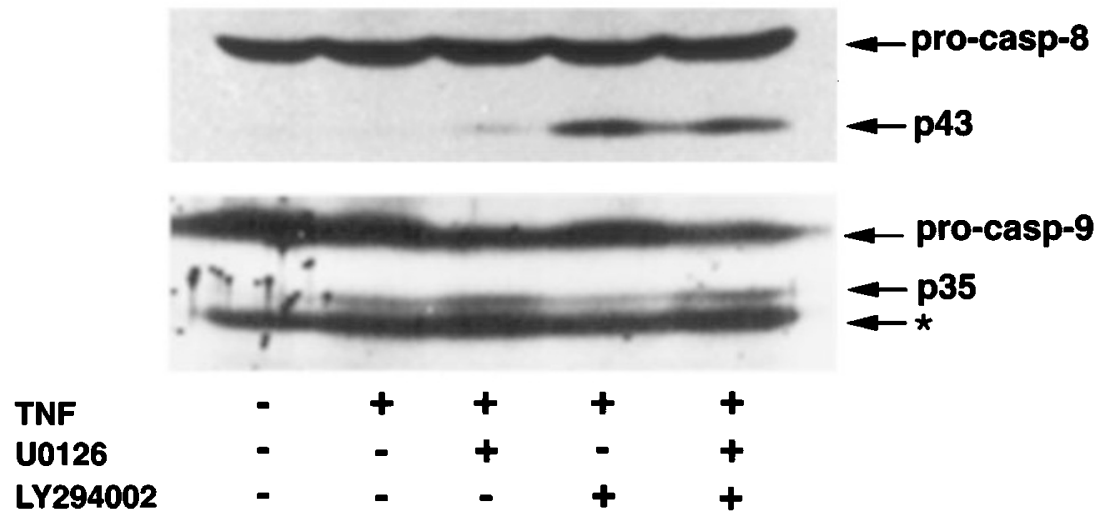

Figure 6 The effect of U0126 or LY294002 on TNF-induced activity of caspase-8 and caspase-9. BAE cells were treated with or without various regents as indicated for $6 \mathrm{~h}, 12 \mathrm{~h}$ or $20 \mathrm{~h}$, then cell lysates were prepared. (A) caspase-8-like protease activity and (B) caspase-9-like protease activity were determined as described in Materials and Methods. Values represent means + S.E.M. $(n=3)$. (C) BAE cells were treated as indicated for $6 \mathrm{~h}$. Cells were lysed and immunoblotted with anti-caspase- 8 antibody (upper panel) or anti-caspase- 9 antibody (lower panel). Asterisk denotes non-specific protein bands. Similar results were obtained from three independent experiments

apoptotic process. TNF provoked caspase-8-like protease activity in BAE cells and inhibition of PI3-kinase/Akt pathway by LY294002 enhanced TNF-induced caspase-8like protease activity 1.5-2-fold, whereas inhibition of MAP kinase pathway did not affect it. Although several studies revealed that PI3-kinase contributes to MAP kinase activation in some paradigms, this result as well as the data shown in Figure $1 \mathrm{~A}$ suggest that MAP kinase and Akt activation induced by TNF are derived from distinct pathways. This result also suggests that PI3-kinase/Akt mediated protection occurred upstream of caspase-8, consistent with the previous observation that PI3-kinase/ Akt-mediated signaling blocks procaspase-8 self-cleavage to its active form. ${ }^{45}$ It is not clear how PI3-kinase/Aktmediated signaling blocks caspase-8-like protease activity. Akt has been demonstrated to phosphorylate procaspase- 9 directly, thus inactivating it. Given the fact that human procaspase-8 also contains the Akt phosphorylation site $\mathrm{RXRXX}(\mathrm{S} / \mathrm{T}) \mathrm{X}$, it is possible that procaspase-8 could be directly phosphorylated by Akt. Alternatively, Akt may affect the functions of FADD or TRADD, and thus interfere with the recruitment of procaspase-8, preventing its activation.
In some cell types, caspase-8 cleaves BID, and truncated BID translocates to mitochondrial outer membrane to induce cytochrome $c$ release, which in turn initiates the caspase- 9 cascade. ${ }^{5,46}$ In our present study, TNF itself induced $20-25 \%$ of cells to undergo apoptosis, suggesting that anti-apoptotic pathways induced by TNF could not completely counteract the death signal in this system. This may explain why we could observe that TNF induced cytochrome $c$ release in a few cells and TNF alone also evoked both caspase-8-like and caspase-9-like protease activity. As mentioned above, inhibition of MAP kinase by U0126 potentiated cytochrome $c$ release. Coincidentally, inhibition of MAP kinase enhanced caspase-9-like protease activity much more than TNF alone. Inhibition of PI3-kinase/Akt pathway also potentiated cytochrome $c$ release; accordingly, we expect that inhibition of the PI3-kinase/Akt pathway may also enhance TNF-induced caspase-9-like protease activity. Surprisingly, pretreatment of cells with LY294002 did not increase TNF-induced caspase-9-like protease activity and this discrepancy led to the speculation that MAP kinase-mediated protective signaling not only interferes 
with the apoptotic process at the level of mitochondria, but also at the level of caspase activation. TNF activates both MAP kinase and Akt in BAE cells, and both of them contribute to the protective effect in the TNF self-control machinery. Since LY294002 could not inhibit TNF-induced MAP kinase activation, MAP kinase-mediated signaling proceed when the PI3-kinase/Akt pathway was blocked by LY294002. This observation may explain why release of cytochrome $c$ induced by LY294002 did not enhance TNF-induced caspase-9-like protease activity. When TNFinduced PI3-kinase/Akt pathway was blocked by LY294002, cytochrome $c$ was released from mitochondria. TNF-induced MAP kinase may affect the formation of functional apoptosome (Apaf-1, cytochrome $c$ and procaspase-9) by some unknown mechanism, thereby inhibiting caspase- 9 activation. This idea is also supported by the observation that the B-Raf/MEK/Erk signaling can inhibit apoptosis downstream of mitochondrial cytochrome $c$ release in fibroblast. ${ }^{22}$ Moreover, MAP kinase pathway has been shown to upregulate the expression of the anti-apoptotic protein $\mathrm{Bcl}-2,{ }^{23}$ and $\mathrm{Bcl}-$ 2 blocks apoptosis not only upstream of mitochondria, but also downstream of cytochrome $c$ in some scenarios. ${ }^{47,48}$ Whether MAP kinase suppresses caspase- 9 activity via upregulation of $\mathrm{Bcl}-2$ expression in our experiment needs further investigation.

In conclusion, the data presented here demonstrate that TNF-induced MAP kinase and PI3-kinase/Akt signaling, which are not related to $\mathrm{NF}-\kappa \mathrm{B}$, are involved in a protective effect against TNF cytotoxicity in BAE cells. MAP kinase maintains the integrity of mitochondria and can also suppress caspase- 9 activity downstream of cytochrome $c$ release while PI3-kinase/Akt-dependent protection may occur upstream both of caspase-8 and mitochondria.

\section{Materials and Methods}

\section{Materials}

Minimum essential medium (MEM) was purchased from GIBCO BRL (Grand Island, NY, USA), fetal bovine serum (FBS) was purchased from JRH Biosciences (Lenexa, KS, USA), and recombinant human TNF- $\alpha$ was obtained from Pepro Tech EC Ltd (London, UK). LY294002 was purchased from Biomol Research Laboratories (Plymouth Meeting, PA, USA). Anti-NF- $k$ B (p65) and anti-ERK antibodies were obtained from Santa Cruz Biotechnology (Santa Cruz, CA, USA), antiphosphorylated Akt and anti- $\kappa_{\kappa} \mathrm{B}$ antibodies were purchased from New England BioLabs (Beverly, MA, USA), anti-active MAP kinase antibody was obtained from Promega (Madison, WI, USA) and anticytochrome $c$ (clone 7H8. 2C12) was purchased from Pharmingen (San Diego, CA, USA). Anti-caspase-8 antibody was obtained from StressGen (Victoria, British Columbia, Canada) and anti-caspase- 9 was purchased from MBL (Nagoya, Japan). Rhodamine 123 and antibovine cytochrome oxidase subunit IV (clone 20E8. C12) were obtained from Molecular Probe (Eugene, OR, USA). All secondary antibodies and ECL kit were from Amersham (UK). Caspase-8 and caspase-9 flourometric assay kits were purchased from R\&D Systems (Minneapolis, MN, USA). The other reagents were purchased from Sigma (St. Louis, MO, USA).

\section{Cell culture and reagents treatment}

BAE cells were cultured in a minimum essential medium (MEM) supplemented with $5 \% \mathrm{FBS}$ in a humidified $\mathrm{CO}_{2}(5 \%)$ incubator until they reached $85-90 \%$ confluence, then serum was deprived from the culture medium for $14 \mathrm{~h}$ before experimental reagent treatments and during all treatment periods. All inhibitors were added $30-45 \mathrm{~min}$ before TNF addition.

\section{Cell survival assay}

Apoptotic cells were determined by Hoechst 33342 staining. After treatment with the respective agents for $20 \mathrm{~h}$, cells were stained with Hoechst 33342. Nuclear DNA staining was examined by fluorescence microscopy. The cells exhibiting condensed or fragmented nuclei were counted as dead cells. The dead and surviving cells from four randomly chosen fields in each well were counted, the apoptotic cells ratio was calculated in each well and averaged from six wells for each treatment.

Cell survival was also detected by MTT assay. The cells were seeded on 96-well plates at a density of 20000 cell/well for $24 \mathrm{~h}$ before treatment. After $20 \mathrm{~h}$ of treatment with various reagents, the cells were incubated with $1 \mathrm{mg} / \mathrm{ml} \mathrm{MTT}$ for $4 \mathrm{~h}$ at $37^{\circ} \mathrm{C}$, then the formazan product was solubilized with $0.04 \mathrm{~N} \mathrm{HCl} /$ iso-propanol. Cell viability was assessed by spectrophotometry at $570 \mathrm{~nm}$ and $650 \mathrm{~nm}$ absorbance.

\section{Detection of caspase-8 and caspase- 9 activity}

Caspase- 8 and caspase- 9 activity was measured using a fluorometric assay kit according to the manufacturer's instructions. Protein concentration was determined by a protein assay kit (Bio-Rad Laboratories, Hercules, CA, USA). Fluorescence was assessed by using a spectrofluorophotometer (SHIMADZU, RF-540) with excitation at $400 \mathrm{~nm}$ and emission at $505 \mathrm{~nm}$.

\section{Detection of mitochondrial transmembrane potential $(\Delta \psi)$}

After $4 \mathrm{~h}$ treatment with the respective agents, cells were incubated with $5 \mu \mathrm{M}$ rhodamine 123 in the presence or absence of $50 \mu \mathrm{M}$ carbonyl cyanide 3-chlorophenylhydrazone (CCCP) for $15 \mathrm{~min}$ at $37^{\circ} \mathrm{C}$. The uptake of rhodamine 123 was measured by flow cytometry.

\section{Immunofluorescence staining}

BAE cells were cultured in 8-well chamber slides in a serum-free MEM overnight, then the cells were treated with inhibitors for $30 \mathrm{~min}$ followed by stimulation with TNF $(10 \mathrm{ng} / \mathrm{ml})$ for the indicated durations. The cells were fixed with $4 \%$ parafomaldehyde for $30 \mathrm{~min}$, then permeabilized for $5 \mathrm{~min}$ with $0.1 \%$ Triton $\mathrm{X}-100$. After incubation with $2 \%$ FBS in phosphate buffered saline (PBS) for $1 \mathrm{~h}$, the cells were incubated with anti-NF- $k B$ (p65) antibody $(1: 200)$ or anti-cytochrome $c$ antibody $(1: 500)$ for $1-2 \mathrm{~h}$ at room temperature. After washing in PBS three times, the cells were incubated with fluorescein isothiocyanate (FITC) conjugated antirabbit IgG $(1: 150$, for anti-NF- $\kappa \mathrm{B}$ antibody) or FITC conjugated anti-mouse IgG (1:100, for anti-cytochrome $c$ antibody) for $1 \mathrm{~h}$ at room temperature. The signals were detected under a fluorescent microscope (BX21, Olympus, Japan).

To examine the specificity of the immunostaining, control slides were incubated with PBS instead of primary antibodies. 


\section{Subcellular fraction preparation and Western blot analysis}

To analyze mitochondrial cytochrome $c$ release, BAE cells were treated with the various experimental reagents for $4 \mathrm{~h}$, then collected and incubated with $10 \mu \mathrm{M}$ digitonin in mitochondrial isolation buffer (20 mM HEPES-KOH, pH 7.5; 250 mM sucrose; 1 mM EDTA; 1 mM dithiothreitol; $1.5 \mathrm{mM} \mathrm{MgCl} 2 ; 10 \mathrm{mM} \mathrm{KCl}$ and protease inhibitor cocktail tablet) at $37^{\circ} \mathrm{C}$ for $5 \mathrm{~min}$. In this treatment condition, the cell membrane was disrupted without mitochondrial membrane damage. ${ }^{49}$ After centrifugation, the supernatant (cytosol) was decanted and saved while the pellets (containing mitochondria) were lysed in a lysis buffer (50 mM Tris-HCl, pH 7.5; 150 mM NaCl; 1\% Nonidet P40; 0.5\% sodium dexycholate; and protease inhibitor cocktail tablet). The amounts of protein were determined by Bio-Rad protein assay, and samples from cytosol and mitochondria fractions were analyzed by Western blotting as described below.

To detect the levels of ERK, active (phosphorylated) MAP kinase, phosphorylated Akt, degradation of $I_{\kappa} \mathrm{B}$, and activation of procaspases, the cells were lysed in the lysis buffer, and the amount of protein in each sample was determined by Bio-Rad protein assay. Equal amounts of protein were subjected to $10 \%$ sodium dodecylsulfate-polyacrylamide gel electrophoresis (SDS-PAGE) (for ERK, I $k \mathrm{~B}-\alpha$, active MAP kinase and phosphorylated Akt), or $15 \%$ SDS-PAGE (for caspase-8, caspase-9, cytochrome $c$ and cytochrome oxidase subunit IV), respectively. After the proteins were transferred onto nitrocellulose membranes, the membranes were blocked with $3 \%$ bovine serum albumin (BSA) (for anti-active MAP kinase and anti-phosphorylated Akt antibodies) or $5 \%$ skim milk (for anti-ERK, anti-cytochrome $c$, anti-cytochrome oxidase subunit IV, anticaspase-8, anti-caspase- 9 and anti- $\left.\right|_{\kappa} \mathrm{B}-\alpha$ antibodies) in Tris-buffered saline containing $0.01 \%$ Tween-20 (TBS/T) for $1 \mathrm{~h}$, then hybridized with the respective antibodies (anti-phosphorylated Akt, 1:1000; antiERK, 1:1000; anti-active MAP kinase, 1:5000; anti- $\left.\right|_{\kappa} \mathrm{B}-\alpha, 1: 1000$; anti-cytochrome $c, 1: 1000$; anti-cytochrome oxidase subunit IV, 1:1000; anti-caspase-8, 1:250; anti-caspase-9, 1:1000) overnight at $4^{\circ} \mathrm{C}$. After washing three times with TBS/T, the membranes were incubated with horseradish peroxidase-conjugated mouse IgG secondary antibody $(1: 5000$; for anti-cytochrome $c$ and anticytochrome oxidase subunit IV antibodies) or horseradish peroxidase-conjugated rabbit IgG secondary antibody (1:5000; for other primary antibodies). The signals were visualized with ECL kit.

\section{Acknowledgements}

We thank Dr. Chong Feng Gao for excellent technical assistance and helpful discussions. This work was supported by The Fujisawa Foundation.

\section{References}

1. Nagata S (1997) Apoptosis by death factor. Cell 88: 355-365

2. Hsu H, Xiong J and Goeddel DV (1995) The TNF receptor 1-associated protein TRADD signals cell death and NF- $\kappa$ B activation. Cell 81: 495-504

3. Hsu H, Shu HB, Pan MG and Goeddel DV (1996) TRADD-TRAF2 and TRADDFADD interactions define two distinct TNF receptor 1 signal transduction pathways. Cell 84: 299-308

4. Liu X, Kim CN, Yang J, Jemmerson R and Wang X (1996) Induction of apoptotic program in cell-free extracts: requirement for dATP and cytochrome c. Cell 86: $147-157$
5. LuoX, Budihardjol, Zou H, SlaughterC Cand Wang X (1998) Bid, a Bcl2 interacting protein, mediates cytochrome $\mathrm{C}$ release from mitochondria in response to activation of cell surface death receptors. Cell 94: 481-490

6. Hsu H, Huang J, Shu HB, Baichwal V and Goeddel DV (1996) TNF-dependent recruitment of the protein kinase RIP to the TNF receptor-1 signaling complex. Immunity 4: 387-396

7. Kelliher MA, Grimm S, Ishida Y, Kuo F, Stanger BZ and Leder P (1998) The death domain kinase RIP mediates the TNF-induced NF- $\kappa$ B signal. Immunity 8: 297 303

8. Lee SY, Reichlin A, Santana A, Sokol KA, Nussenzweig MC and Choi Y (1997) TRAF2 is essential for JNK but not NF- $k B$ activation and regulates lymphocyte proliferation and survival. Immunity 7: 703-713

9. Nophar Y, Holtmann H, Ber R and Wallach D (1988) Dominance of resistance to the cytocidal effect of tumor necrosis factor in heterokaryons formed by fusion of resistant and sensitive cells. J. Immunol. 140: 3456-3460

10. Leist M, Gantner F, Bohlinger I, Germann PG, Tiegs G and Wendel A (1994) Murine hepatocyte apoptosis induced in vitro and in vivo by TNF- $\alpha$ requires transcriptional arrest. J. Immunol. 153: 1778-1788

11. Wallach D (1997) Cell death induction by TNF: a matter of self control. Trends Biochem. Sci. 22: $107-109$

12. Beyaert R and Fiers W (1994) Molecular mechanisms of tumor necrosis factorinduced cytotoxicity. What we do understand and what we do not. FEBS Lett. 340: $9-16$

13. Chu ZL, McKinsey TA, Liu L, Gentry JJ, Malim MH and Ballard DW (1997) Suppression of tumor necrosis factor-induced cell death by inhibitor of apoptosis c-IAP2 is under NF- $\kappa$ B control. Proc. Natl. Acad. Sci. USA 94: 10057-10062

14. Van Antwerp DJ, Martin SJ, Verma IM and Green DR (1998) Inhibition of TNFinduced apoptosis by NF- $\kappa$ B. Trends Cell. Biol. 8: 107-111

15. Van Antwerp DJ, Martin SJ, Kafri T, Green DRand Verma IM (1996) Suppression of TNF- $\alpha$-induced apoptosis by NF- $\kappa$ B. Science 274: 787-789

16. Beg AA and Baltimore $D$ (1996) An essential role for NF- $\kappa B$ in preventing TNF- $\alpha-$ induced cell death. Science 274: $782-784$

17. Wang CY, Mayo MW and Baldwin Jr A (1996) TNF- and cancer therapy-induced apoptosis: potentiation by inhibition of NF- $k$ B. Science 274: 784-787

18. Wang CY, Mayo MW, Korneluk RG, Goeddel DV and Baldwin Jr A (1998) NF- $\kappa B$ antiapoptosis: induction of TRAF1 and TRAF2 and C-IAP1 and c-IAP2 to suppress caspase-8 activation. Science 281: 1680-1683

19. Yeh WC, Shahinian A, Speiser D, Kraunus J, Billia F, Wakeham A, de la Pompa JL, Ferrick D, Hum B, Iscove N, Ohashi P, Rothe M, Goeddel DV and Mak TW (1997) Early lethality, functional NF- $\kappa$ B activation, and increased sensitivity to TNF-induced cell death in TRAF2-deficient mice. Immunity 7: 715-725

20. Dudek H, Datta SR, Franke TF, Birnbaum MJ, Yao R, Cooper GM, Segal RA, Kaplan DR and Greenberg ME (1997) Regulation of neuronal survival by the serine-threonine protein kinase Akt. Science 275: 661-665

21. Datta SR, Brunet A and Greenberg ME (1999) Cellular survival: a play in three Akts. Genes Dev. 13: 2905-2927

22. Erhardt P, Schremser EJ and Cooper GM (1999) B-Raf inhibits programmed cell death downstream of cytochrome $c$ release from mitochondria by activating the MEK/Erk pathway. Mol. Cell. Biol. 19: 5308-5315

23. Bonni A, Brunet A, West AE, Datta SR, Takasu MA and Greenberg ME (1999) Cell survival promoted by the Ras-MAPK signaling pathway by transcriptiondependent and -independent mechanisms. Science 286: 1358-1362

24. Xia Z, Dickens M, Raingeaud J, Davis RJ and Greenberg ME (1995) Opposing effects of ERK and JNK-p38 MAP kinases on apoptosis. Science 270: 13261331

25. Cardone MH, Roy N, Stennicke HR, Salvesen GS, Franke TF, Stanbridge E, Frisch S and Reed JC (1998) Regulation of cell death protease caspase-9 by phosphorylation. Science 282: 1318-1321

26. Datta SR, Dudek H, Tao X, Masters S, Fu H, Gotoh Y and Greenberg ME (1997) Akt phosphorylation of BAD couples survival signals to the cell-intrinsic death machinery. Cell 91: 231-241

27. Brunet A, Bonni A, Zigmond MJ, Lin MZ, Juo P, Hu LS, Anderson MJ, Arden KC, Blenis J and Greenberg ME (1999) Akt promotes cell survival by phosphorylating and inhibiting a Forkhead transcription factor. Cell 96: 857-868

28. Ozes ON, Mayo LD, Gustin JA, Pfeffer SR, Pfeffer LM and Donner DB (1999) NF$\kappa$ B activation by tumour necrosis factor requires the Akt serine-threonine kinase. Nature 401: $82-85$ 
29. Romashkova JA and Makarov SS (1999) NF- $\kappa$ B is a target of AKT in antiapoptotic PDGF signalling. Nature 401: $86-90$

30. Ghoda L, Lin X and Greene WC (1997) The 90-kDa ribosomal S6 kinase (pp90rsk) phosphorylates the N-terminal regulatory domain of $\mathrm{I} \kappa \mathrm{B} \alpha$ and stimulates its degradation in vitro. J. Biol. Chem. 272: 21281-21288

31. Schouten GJ, Vertegaal AC, Whiteside ST, Israel A, Toebes M, Dorsman JC, van derEb AJ and Zantema $A(1997) I_{\kappa} \mathrm{B} \alpha$ is a target for the mitogen-activated $90 \mathrm{kDa}$ ribosomal S6 kinase. EMBO J. 16: 3133-3144

32. Beg AA and Baldwin Jr A (1993) The $I_{\kappa} B$ proteins: multifunctional regulators of Rel/NF- $k$ B transcription factors. Genes Dev. 7: 2064-2070

33. Green D and Kroemer G (1998) The central executioners of apoptosis: caspases or mitochondria? Trends in Cell. Biol. 8: 267-271

34. Kroemer G and Reed J (2000) Mitochondrial control of cell death. Nature Med. 6 : 513-519

35. Guo YL, Kang B and Williamson JR (1999) Resistance to TNF- $\alpha$ cytotoxicity can be achieved through different signaling pathways in rat mesangial cells. Am. J. Physiol. 276: C435-441

36. Xia P, Wang L, Gamble JR and Vadas MA (1999) Activation of sphingosine kinase by tumor necrosis factor- $\alpha$ inhibits apoptosis in human endothelial cells. J. Biol. Chem. 274: 34499-34505

37. Holmstrom TH, Chow SC, Elo I, Coffey ET, Orrenius S, Sistonen L and Eriksson JE (1998) Suppression of Fas/APO-1-mediated apoptosis by mitogen-activated kinase signaling. J. Immunol. 160: 2626-2636

38. Kennedy SG, Kandel ES, Cross TK and Hay N (1999) Akt/Protein kinase B inhibits cell death by preventing the release of cytochrome $c$ from mitochondria. Mol. Cell. Biol. 19: 5800-5810

39. Gibson S, Tu S, Oyer R, Anderson SM and Johnson GL (1999) Epidermal growth factor protects epithelial cells against Fas-induced apoptosis. Requirement for Akt activation. J. Biol. Chem. 274: 17612-17618
40. Pastorino JG, Tafani M and Farber JL (1999) Tumor necrosis factor induces phosphorylation and translocation of BAD through a phosphatidylinositide-3-OH kinase-dependent pathway. J. Biol. Chem. 274: 19411-19416

41. Madge LA and Pober JS (2000) A phosphatidylinositol 3-kinase/Akt pathway, activated by tumornecrosis factor or interleukin-1, inhibits apoptosis but does not activate NF- $\kappa$ B in human endothelial cells. J. Biol. Chem. 275: 15458-15465

42. Yao B, Zhang Y, Delikat S, Mathias S, Basu S and Kolesnick R (1995) Phosphorylation of Raf by ceramide-activated protein kinase. Nature 378: 307 310

43. Guo D and Donner DB (1996) Tumor necrosis factor promotes phosphorylation and binding of insulin receptor substrate 1 to phosphatidylinositol 3-kinase in 3T3-L1 adipocytes. J. Biol. Chem. 271: 615-618

44. Hanna AN, Chan EY, Xu J, Stone JC and Brindley DN (1999) A novel pathway for tumor necrosis factor- $\alpha$ and ceramide signaling involving sequential activation of tyrosine kinase, p21(ras), and phosphatidylinositol 3-kinase. J. Biol. Chem. 274: $12722-12729$

45. Varadhachary AS, Peter ME, Perdow SN, Krammer PH and Salgame P (1999) Selective up-regulation of phosphatidylinositol 3 '-kinase activity in Th2 cells inhibits caspase-8 cleavage at the death-inducing complex: a mechanism for Th2 resistance from Fas-mediated apoptosis. J. Immunol. 163: 4772-4779

46. LiH, Zhu H, Xu CJ and Yuan J (1998) Cleavage of BID by caspase 8 mediates the mitochondrial damage in the Fas pathway of apoptosis. Cell 94: 491-501

47. Rosse T, Olivier R, Monney L, Rager M, Conus S, Fellay I, Jansen B and Borner C (1998) Bcl-2 prolongs cell survival after Bax-induced release of cytochrome C. Nature 391: $496-499$

48. Zhivotovsky B, Orrenius S, Brustugun TO and Doskeland SO (1998) Injected cytochrome $c$ induces apoptosis. Nature 391: 449-450

49. Eguchi Y, Srinivasan A, Tomaselli KJ, Shimizu S and Tsujimoto Y (1999) ATPdependent steps in apoptotic signal transduction. Cancer Res. 59: 2174-2181 